\title{
WIELOASPEKTOWE PODEJŚCIE DO DEFINICJI PRODUKTU TURYSTYCZNEGO
}

\begin{abstract}
Przedmiotem obrotu na rynku usług turystycznych jest produkt turystyczny. Jest to pojęcie złożone i różnie definiowane w zależności od celu prowadzonych badań, podmiotu, z którego punktu widzenia dostrzega się korzyści płynące z produktu, branego pod uwagę zakresu znaczeniowego czy liczby elementów tworzących produkt. Produkt turystyczny ma specyficzne cechy, które odróżniają go od produktów na innych rynkach i determinują sposób funkcjonowania uczestników rynku. Integralną częścią produktu są dobra i usługi. W zależności od autorów definiujących produkt turystyczny można w jego strukturze wyróżnić: walory turystyczne, infrastrukturę turystyczną i towarzyszące im usługi, podstawowe dobra turystyczna i bazę turystyczną oraz podstawowe i komplementarne usługi turystyczne. Nie wszystkie części składowe produktu turystycznego są uchwytne i dlatego w marketingowym podejściu do zagadnienia produkt ,zaczyna się" w momencie wyboru miejsca wypoczynku i trwa długo po powrocie przy wakacyjnych wspomnieniach. Zachodzące w światowej gospodarce zmiany inicjują nowatorskie podejścia przy tworzeniu produktów turystycznych, czego najlepszym przykładem jest integralny produkt turystyczny budowany przy współudziale samorządu lokalnego, sektora prywatnego i lokalnej społeczności. Autor artykułu dokonał przeglądu istniejących współcześnie definicji produktu turystycznego i ustosunkował się do kwestii ich wielości w aspekcie rzeczywistego zapotrzebowania na nie ze strony osób badających rynki turystyczne. Bazowanie na jednej uogólnionej i uniwersalnej definicji nie jest wskazane przy prowadzeniu konkretnych badań.
\end{abstract}

Słowa kluczowe: rynek turystyczny, produkt turystyczny

\section{WPROWADZENIE}

W krajach rozwiniętych podstawą gospodarki są usługi, które dostarczają klientom doświadczeń mocno naznaczonych emocjami. ${ }^{2}$ Wpisują się one w gospodarkę doświadczeń, której rozwój, jak pisze Andrzej Stasiak², rozpoczął się na przełomie XX i XXI w. Turystykę określa się jako ,przemysł wakacyjnych doświadczeń”, silnie akcentując rangę emocji przy tworzeniu produktów turystycznych. Do przedsięwzięć, które intensyfikują wrażenia i emocje turysty, zalicza się $e^{4}$ :

- $\quad$ kreowanie unikatowych atrakcji turystycznych na bazie infrastruktury turystycznej;

\footnotetext{
${ }^{1}$ Artur Stec, dr inż., Wydział Zarządzania, Politechnika Rzeszowska, Rzeszów, ul. Powstańców Warszawy 12, e-mail: artistec@ prz.edu.pl, tel.: 178651848

${ }^{2}$ M. Nowacki, Szlaki dziedzictwa naturalnego i kulturowego droga ku turystyce kreatywnej, [w:] Kultura i turystyka. Wspólna droga, red. B. Włodarczyk, B. Krakowiak, J. Latosińska, Regionalna Organizacja Turystyczna Województwa Łódzkiego, Łódź 2011, s. 11-28.

${ }^{3}$ A. Stasiak, Produkt turystyczny w gospodarce doświadczeń, „Turyzm” 23/1 (2013), s. 29-30.

${ }^{4}$ Ibidem, s. 30.
} 
i emocje

wzbogacanie istniejących produktów turystycznych o doświadczenia

- $\quad$ tworzenie tzw. rozszerzonej rzeczywistości;

- $\quad$ stosowanie nowych form zapisu doświadczeń turystycznych i dzielenia się nimi;

- $\quad$ opracowywanie nowych przestrzeni turystycznych w celu zagwarantowania niezapomnianych przeżyć i ekstremalnych doznań;

- propagowanie rozwoju nowych form turystyki zapewniających specyficzne emocje i rozwijających u turysty kreatywność i osobowość.

Produkt turystyczny jest przedmiotem obrotu na rynku usług turystycznych. Może on występować w formie dobra, usługi lub być kombinacją dóbr i usług. W sektorze usług turystycznych istnieje wielość definicji produktu. Produktem turystycznym określa się ofertę biura podróży, potencjał turystyczny jednostki terytorialnej, szlak tematyczny, ścieżkę przyrodniczą czy festiwal muzyczny. Czy istnieje konieczność stosowania różnorodnych definicji produktu turystycznego? Czy nie można byłoby w każdym wypadku używać jednej uniwersalnej definicji produktu turystycznego? Artykuł ma na celu dokonanie przeglądu definicji ,produktu turystycznego" konstruowanych na potrzeby badań o charakterze zarówno ekonomicznym, jak i marketingowym przy uwzględnieniu różnic w jego postrzeganiu przez oferodawcę i turystę. Ponadto w artykule dokonano identyfikacji rodzajów produktów turystycznych, jego części składowych oraz cech odróżniających go od innych produktów.

\section{PRZEGLĄD DEFINICJI PRODUKTU TURYSTYCZNEGO}

Produktem można określić wszystko, co jest przedmiotem wymiany. Za produkt można także uznać ofertę sprzedawcy lub jego propozycję, która zostanie zweryfikowana przez rynek. Produktem jest wszystko to, co nadaje się do konsumpcji, użytkowania lub dalszego przerobu, a więc mogą nim być nie tylko przedmioty, ale również usługi, czynności, osoby, idee, pomysły, miejsca czy pomysły organizacyjne oraz technologiczne. Philip Kotler ${ }^{5}$ względem produktu użył synonimu ,pakiet korzyści” oraz „,wiązka korzyści” i zaznaczył, że dla nabywcy stanowi on zbiór oczekiwań i korzyści (przyjemności i użyteczności). W produkcie kupujący dostrzega zyski, jakie przyniesie zakup, stąd też w trakcie dokonywania tej czynności uwaga jest skupiona na opakowaniu, czyli wspomnianych wcześniej korzyściach i pożytkach. Dopiero w trakcie procesu konsumpcji można ich doświadczyć.

W odniesieniu do produktu turystycznego często stosuje się definicję sformułowaną przez Claude Kaspara ${ }^{6}$, który opisuje go jako przedmiot materialny lub usługę wykorzystywane przez turystę podczas podróży. Jerzy Dietl ${ }^{7}$ wiąże produkt turystyczny z tym, co kupuje się w celu zaspokojenia potrzeb i preferencji w czasie zmiany miejsca pobytu, motywowanej destynacją turystyczną. Jost Kripendorf ${ }^{8}$ pod pojęciem produktu turystycznego rozumie czynniki naturalne (fauna, flora, klimat, pejzaż), czynniki egzystencji i aktywności społecznej (kultura, folklor, język, polityka, ekonomia), infrastrukturę ogól-

\footnotetext{
${ }^{5} \mathrm{Ph}$. Kotler, Principles of Marketing. Englewood Cliffs, Prentice Hall, Englewood Cliffs 1980, s. 386.

${ }^{6}$ C. Kaspar, B. Kunz, Unternehmungsführung im Fremdenverkehr, Stuttgart, Bern 1982, s. 34.

${ }^{7}$ J. Dietl, Marketing, PWE, Warszawa 1981, s. 31.

${ }^{8}$ J. Krippendorf, Marketing im Fremdenverker, Bern-Frankfurt 1971, s. 124.
} 
ną (zaopatrzenie w wodę, energię, komunikacja), a także wyposażenie turystyczne (baza noclegowa, żywieniowa, rozrywkowa, informacyjna, transport).

Dariusz Fijałkowski ${ }^{9}$ definiuje produkt turystyczny na podstawie przytoczonych definicji jako zbiór walorów turystycznych, z których turyści korzystają i stanowią dla nich przedmiot zainteresowania, oraz jako dobra i usługi nabywane przez turystów. Podstawowym elementem produktu turystycznego są walory turystyczne. Spełniają jedynie wtedy swoją funkcję, gdy są zespolone $\mathrm{z}$ dobrami i usługami turystycznymi w jeden produkt turystyczny. O uznaniu danego waloru za atrakcję turystyczną przesądzają odpowiednie usługi. W każdej z zaprezentowanych definicji zwraca się uwagę na materialny i niematerialny aspekt produktu turystycznego.

Slavoj Medlik ${ }^{10}$ wyróżnił produkt w wąskim znaczeniu (sensu stricto) i w szerokim znaczeniu (sensu largo). W wąskim znaczeniu produkt turystyczny jest tożsamy z tym, co turyści kupują osobno (bilet autobusowy, posiłek, nocleg, bilet na zawody sportowe) lub w formie pakietu usług. W szerokim znaczeniu za produkt można uznać wszystko, co turyści robią i z czego korzystają podczas podróży oraz w miejscu pobytu (walory, urządzenia, usługi). Produktem z punktu widzenia turysty jest w tym sensie całość przeżytego doświadczenia od momentu opuszczenia domu aż do powrotu

Jacek Kaczmarek ${ }^{11}$ podkreślił, że chociaż turystyka należy do sektora usługowego, to nie można umniejszać znaczenia materialnych składników produktu turystycznego. Gdyby one nie istniały, nie byłoby możliwości świadczenia usług (np. noclegowej). Dobra materialne można podzielić na walory i zagospodarowanie turystyczne. Organizator turystyki nie musi być ich właścicielem, aby mogły zostać zaoferowane turystom. Ponadto konsumenci nie stają się właścicielami dóbr, a jedynie nabywają prawo do okresowego korzystania z nich (np. do noclegu, korzystania z restauracji). Warunkami powstania produktu turystycznego są w jego ramach koegzystencja dóbr i usług oraz podporządkowanie nadrzędnej idei (pomysł na produkt i jego organizacja rozumiana jako sprawne i logiczne połączenie składników czy też fachowa produkcja). W ten sposób powstaje, według terminologii Medlika, produkt sensu stricto, czyli pakiet turystyczny. Jego jakość jest wyłącznie determinowana cechami opisującymi poziom obsługi organizatora (rzetelność, profesjonalizm, dbałość o jakość usług cząstkowych).

Podobnie produkt scharakteryzował Kazimierz Rogoziński ${ }^{12}$, który w jego ramach wydzielił następujące szczegółowe elementy:

- walory turystyczne (podstawowe dobra turystyczne):

- walory naturalne,

- walory antropogeniczne stworzone przez człowieka,

- ogólne czynniki egzystencji oraz aktywności społecznej (język, folklor, gospodarka, itp.);

- komplementarne dobra turystyczne:

a) dostępność miejsca docelowego,

- $\quad$ infrastruktura (sieć drogowa i kolejowa, porty lotnicze),

\footnotetext{
${ }^{9}$ D. Fijałkowski, Produkt turystyczny w ujęciu marketingowym, „Słupskie Prace Geograficzne” 2003/1, s. 81.

${ }^{10}$ S. Medlik, Leksykon podróży, turystyki i hotelarstwa, Państwowe Wydawnictwo Naukowe, Warszawa 1995, s. 243.

${ }^{11}$ J. Kaczmarek, A. Stasiak, B. Włodarczyk, Produkt turystyczny, „Turystyka i hotelarstwo” 2002/1, s. 35.

${ }^{12}$ K. Rogoziński, Marketing na rynku turystycznym, „Handel Wewnętrzny” 1977/4, s. 7.
} 
- $\quad$ sprzęt (liczba i wielkość środków transportowych, szybkość taboru),

- $\quad$ czynniki eksploatacyjne (częstotliwość połączeń),

- regulacje rządowe dotyczące transportu (przede wszystkim lotniczego),

b) infrastruktura miejsca docelowego:

- baza noclegowa,

- baza gastronomiczna,

- obiekty rekreacyjne i rozrywkowe,

- $\quad$ sieć punktów sprzedaży detalicznej (sklepy spożywcze i pamiątkarskie),

- $\quad$ transport w miejscu docelowym;

- dobra o charakterze materialnym i usługi świadczone przez wytwórców, które pozwalają turyście na przybycie, przebywanie i korzystanie z walorów turystycznych:

- usługi transportowe,

- usługi noclegowe,

- usługi gastronomiczne,

- $\quad$ usługi umożliwiające aktywny wypoczynek (szkółki narciarskie, kluby golfowe, tenisowe, szkółki jeździeckie)

- pamiątki, mapy, przewodniki;

- udogodnienia (sieć energetyczna i gazowa, ochrona zdrowia, bezpieczeństwo publiczne).

Definicja ta kładzie szczególny nacisk na rolę podstawowych dóbr turystycznych. Są one w turystyce rekreacyjnej inspiracją do podróżowania. Pomija ona jednak takie formy uprawiania turystyki jak turystyka służbowa czy edukacyjna. Nieprecyzyjnie jest także ujęta rola „udogodnień”, ponieważ są one częścią infrastruktury i nie ma potrzeby ich kupowania po określonej cenie. Tak sformułowana definicja dotyczy przede wszystkim produktu turystycznego występującego $\mathrm{w}$ formie regionu turystycznego, a nie produktu sprzedawanego przez przedsiębiorstwo.

Zakupiony zestaw dóbr i usług można uznać za „trzon produktu”. Niemniej jednak należy wziąć pod uwagę także jego „otoczenie”, czyli pogodę podczas wypoczynku, nawiązane $\mathrm{w}$ trakcie urlopu przyjaźnie, indywidualne przeżycia turysty, nabyte umiejętności i doświadczenia, wizerunek miejsca wypoczynku. Miejsce destynacji turystycznej może być w świadomości społecznej uznawane za prestiżowe, nobilitujące, ekstrawaganckie, egzotyczne. Odbiór odwiedzanego obszaru jest najtrudniejszym do oceny elementem produktu turystycznego. Wpływ organizatora na „otoczenie” jest niewielki, choć ocena właśnie tego elementu rzutuje przede wszystkim na ocenę jego działalności. Organizator może jedynie próbować ograniczać ryzyko pojawienia się niekorzystnych zdarzeń poprzez na przykład wynajęcie profesjonalnej firmy ochroniarskiej w celu zapewnienia bezpieczeństwa uczestnikom eventu, zorganizowanie festiwalu $\mathrm{w}$ hali $\mathrm{w}$ razie załamania pogody czy wysyłanie turystów na letni wypoczynek do krajów śródziemnomorskich, gdzie pewna jest słoneczna aura. Od strony potencjalnego turysty, rozważającego określoną podróż, za produkt turystyczny można więc uznać kompleks materialnych (fizycznych) i niematerialnych (psychologicznych i symbolicznych) właściwości, takich jak struktura, jakość (standard, klasa, prestiż), oznakowanie, cena, dostępność, wygoda naby- 
cia, w których nabywca może dojrzeć przymioty, jeśli zaspokajają jego potrzeby i są źródłem jego satysfakcji ${ }^{13}$.

Władysław Gaworecki ${ }^{14}$ zaznacza, że przy projektowaniu produktu turystycznego powinno się wyjść od motywów, jakimi kieruje się turysta, podejmując decyzję o podróżowaniu. W tym kontekście turyści starają się zaspokoić następujące potrzeby:

- odpoczynku w nadającym się do tego intersującym środowisku przyrodniczym (np. w górach, nad morzem, nad jeziorem);

- eksploracji ciekawych form środowiska naturalnego (np. dolin, gejzerów, jaskiń);

- $\quad$ korzystania z dóbr kultury (np. zwiedzanie muzeów, galerii sztuki, odwiedzanie galerii handlowych);

- $\quad$ poznawania miejsc kultu religijnego (pielgrzymki do miejsc świętych);

- $\quad$ polepszenia stanu zdrowia (np. wyjazdy do sanatoriów);

- uczestnictwa w okolicznościowych wydarzeniach (np. mistrzostwa świata w piłce nożnej, festiwale muzyczne);

- podjęcie kształcenia;

- odwiedziny rodziny i znajomych;

- zawodowe (np. uczestnictwo w konferencjach, seminariach, spotkania biznesowe).

Wymienione motywacje można określić mianem walorów turystycznych. Stanowią je elementy środowiska geograficznego, znajdujące się w kręgu zainteresowania turysty, dla których podejmuje się on wyjazdu do danego regionu lub danej miejscowości. Walory turystyczne, jak wcześniej wspomniano, dzieli się na naturalne (przyrodnicze) i kulturowe (antropogeniczne). Podziału walorów można również dokonać na podstawie kryterium funkcjonalnego. W tym układzie można wyróżnić ${ }^{15}$ :

- walory wypoczynkowe;

- walory specjalistyczne (np. uzdrowiskowe, turystyka jeździecka, nurkowanie, taternictwo);

- walory krajoznawcze (poznawcze), do których zalicza się między innymi walory krajobrazowe, dobra kultury, sztukę ludową, folklor, współczesne osiągnięcia człowieka.

Usługi, które są także częścią składową produktu turystycznego, dzieli się na podstawowe i komplementarne (uzupełniające) ${ }^{16}$. Usługi podstawowe zaspokajają potrzeby materialne, natomiast usługi komplementarne obejmują czynności, które przyczyniają się do urzeczywistnienia potrzeb turysty. Zestaw usług, które świadczy się, aby kompleksowo zaspokoić oczekiwania turysty, nazywa się ,"pakietem usług" ${ }^{17}$. Taki pakiet może się składać z zaledwie dwóch usług (np. noclegi i wyżywienia), ale może także być wieloskładnikowy (przelot samolotem, autokarami, noclegi, posiłki i zwiedzanie atrakcji). Wielu sprzedawców pakietów dodatkowo, w zależności od potrzeb turystów, stwarza im możliwość dokupienia usług uzupełniających.

\footnotetext{
${ }^{13}$ Kompedium wiedzy o turystyce, red. G. Gołembski, PWN, Warszawa-Poznań 2005, s. 68.

${ }^{14}$ W.W. Gaworecki, Ekonomika i organizacja turystyki, PWN, Warszawa 1978, s. 17-18.

${ }^{15}$ A. Panasiuk, Ekonomika turystyki, Wydawnictwo Naukowe PWN, Warszawa 2007, s. 112.

${ }^{16}$ D. Fijałkowski, op. cit., s. 84.

${ }^{17}$ J. Altkorn, Marketing w turystyce, Wydawnictwo Naukowe PWN, Warszawa 1997, s. 99.
} 
Z punktu widzenia przedsiębiorstwa turystycznego za produkt można uznać wszystko, co wpisuje się w jego ofertę bez względu na to, czy ma charakter materialny, czy niematerialny. Popyt nabywców wyznacza asortyment, który staje się przedmiotem wymiany. Podaż turystyczna jest więc kształtowana przez walory turystyczne i dlatego w literaturze często określa się je jako podstawowe dobra turystyczne. Olaf Rogalewski ${ }^{18}$ dobra i urządzenia turystyczne, nazywane bazą turystyczną, podzielił na:

- komunikacyjną;

- noclegową;

- $\quad$ żywieniową;

- $\quad$ uzupełniającą.

Produkt turystyczny można rozpatrywać również w kategorii w realizacji polityki społecznej rządu w zakresie organizacji wypoczynku oraz rozwoju kulturowego ludzi. Rozwój usług turystycznych może się przyczyniać do wzrostu gospodarczego przez aktywizację gospodarek lokalnych i regionalnych. Ponadto turystyka generuje miejsca pracy, zmniejszając bezrobocie.

\section{RODZAJE PRODUKTÓW TURYSTYCZNYCH}

Rozpatrując charakter produktów turystycznych, można je podzielić na produkty proste i produkty złożone. Te drugie są zbudowane z produktów prostych. Produkty proste są złożone z łatwo dającej się wyodrębnić usługi lub dobra materialnego. Niekiedy na produkt prosty składa się kilka usług lub dóbr, które są ściśle ze sobą powiązane. Bez problemu można zidentyfikować producenta, którym jest najczęściej jeden podmiot gospodarczy. Można wyróżnić następujące kategorie prostych produktów turystycznych ${ }^{19}$ :

- $\quad$ produkt turystyczny - usługa;

- $\quad$ produkt turystyczny - rzecz;

- $\quad$ produkt turystyczny - obiekt;

- $\quad$ produkt turystyczny - miejsce.

Produkt turystyczny - usługa występuje w postaci pojedynczej usługi, na przykład noclegowej, żywieniowej, przewodnickiej, transportowej. Produkt turystyczny - rzecz może istnieć samodzielnie, choć często bywa dodatkiem do innych produktów. Ma on wyłącznie postać materialną - na przykład przewodnik, sprzęt turystyczny, pamiątka. $\mathrm{Na}$ rynku współcześnie pojawił się nowy rodzaj produktu turystycznego, który również można zaliczyć do tej kategorii, a mianowicie produkt multimedialny. Obejmuje on multimedialne plany miast, przewodniki po zabytkach, prezentacje atrakcji turystycznych w regionach na płytach CD ROM oraz informacje turystyczne znajdujące się na stronach WWW. Produkt turystyczny - obiekt cechuje występowanie jednej przewodniej atrakcji i związanej z nim usługi oraz kilku dodatkowych usług towarzyszących, które są świadczone w jednym obiekcie o charakterze punktowym (muzeum, galeria sztuki, stadion, hala widowiskowo-sportowa, ośrodek wypoczynkowo-sanatoryjny, jaskinia, pomnik przyrody). Produkt turystyczny - wydarzenie powinien być spójny tematycznie, odpowiednio zorganizowany, a także umiejscowiony w czasie i przestrzeni. Powinien się wyróżniać niecodziennością, wyjątkowością, a często cyklicznością. Przykładem mogą być festiwal muzyczny, impreza sportowa, wystawa czy pokaz. Produkt ten może funkcjonować sa-

\footnotetext{
${ }^{18}$ O. Rogalewski, Zagospodarowanie turystyczne, Wydawnictwa Szkolne i Pedagogiczne, Warszawa 1979, s. 12.

${ }^{19}$ J. Kaczmarek, A. Stasiak, B. Włodarczyk, op. cit., s. 37.
} 
modzielnie lub wchodzić w skład produktu w znaczeniu imprezy lub miejsca (Festiwal Polonijnych Zespołów Folklorystycznych, mistrzostwa świata w piłce nożnej, Pokaz Ogni Sztucznych i Laserów w Olsztynie koło Częstochowy).

Bez wątpienia bardziej rozbudowane, a zarazem skomplikowane są produkty złożone. Mogą być produkowane zarówno przez podmioty gospodarcze (touroperatorzy), jak i organizacje non profit (samorządy lokalne, stowarzyszenia). Produkt finalny jest efektem połączenia kilku produktów cząstkowych i dlatego w osiągnięciu sukcesu rynkowego niezwykle istotna jest współpraca pomiędzy dostawcami poszczególnych jego elementów. Można w tym wypadku wymienić następujące rodzaje produktów złożonych:

- $\quad$ produkt turystyczny - impreza;

- $\quad$ produkt turystyczny - miejsce (obszar);

- $\quad$ produkt turystyczny - szlak.

Produkt turystyczny - impreza jest najpopularniejszą kategorią produktów turystycznych, jakie znajdują się na rynku. Składa się najczęściej z kilku usług lub usług i dóbr materialnych i jest wytwarzany przez touroperatorów lub agentów turystycznych i oferowany w formie pakietu turystycznego. Do tej formy produktu można przyporządkować wycieczki, rajdy, wczasy. Produkt turystyczny - miejsce wyodrębnia się na podstawie kryterium geograficznego i może dotyczyć miejscowości, powiatu, regionu. Jest on konsekwencją rozwoju „marketingu miejsc”. Kierując ofertę miejsca do nabywców, oferuje się walory naturalne i antropogeniczne oraz usługi, których świadczeniem zajmują się podmioty gospodarcze w oparciu na posiadanym zagospodarowaniu turystycznym i paraturystycznym, dziedzictwie kulturowym i historycznym, gościnności i nastawieniu mieszkańców, wizerunku obszaru, a nawet zdarzeń mogących się pojawić podczas wypoczynku turysty. Warunkiem uznania za takie „miejsce” danego obszaru jest według Hanny Zawistowskiej ${ }^{20}$ :

- $\quad$ posiadanie dobra i usługi wspólnych cech;

- $\quad$ rozpoznawalność dóbr i usług pod wspólnym znakiem;

- $\quad$ istnienie prywatnej lub publicznej organizacji odpowiedzialnej za zarządzanie obszarem.

Specyficzną odmianą produktu turystycznego - miejsce jest produkt turystyczny szlak. Są to połączone „miejsca” lub „obiekty” wpisane w nadrzędną ideę i oznaczone jako trasa (piesza, rowerowa, konna, samochodowa). Częścią tak rozumianego produktu jest różnorodna infrastruktura towarzysząca szlakowi. Przykładem mogą być Szlak Architektury Drewnianej, Szlak Gniazd Rodowych Lubomirskich, Szlak Naftowy ${ }^{21}$. W tabeli 1 zaprezentowano różne kategorie produktu turystycznego.

\footnotetext{
${ }^{20}$ H. Zawistowska, Rola Unii Europejskiej w poprawie jakości produktów turystycznych, [w:] Kierunki rozwoju badań naukowych $w$ turystyce, red. G. Gołembski, PWN, Akademia Ekonomiczna w Poznaniu, Warszawa 2003, s. 69

${ }^{21}$ J. Kaczmarek, A. Stasiak, B. Włodarczyk, op. cit., s. 37-39.
} 
Tabela 1. Kategorie produktu turystycznego

\begin{tabular}{|c|c|c|}
\hline \multicolumn{2}{|c|}{ RODZAJ PRODUKTU TURYSTYCZNEGO } & PRZYKŁADY \\
\hline \multirow{4}{*}{$\begin{array}{l}\text { PRODUKTY TURY- } \\
\text { STYCZNE PROSTE }\end{array}$} & USŁUGA & $\begin{array}{l}\text { Usługa noclegowa } \\
\text { Usługa żywieniowa } \\
\text { Przewodnictwo } \\
\text { Wynajem samochodu }\end{array}$ \\
\hline & RZECZ & $\begin{array}{l}\text { Przewodnik turystyczny } \\
\text { Sprzęt turystyczny } \\
\text { Pamiątka } \\
\text { Przewodnik multimedialny } \\
\text { Strona WWW }\end{array}$ \\
\hline & OBIEKT & $\begin{array}{l}\text { Zabytek } \\
\text { Hala widowiskowo- } \\
\text { sportowa } \\
\text { Muzeum } \\
\text { Pomnik przyrody }\end{array}$ \\
\hline & WYDARZENIE & $\begin{array}{l}\text { Wydarzenie sportowe } \\
\text { Pokaz } \\
\text { Festiwal muzyczny } \\
\text { Wystawa }\end{array}$ \\
\hline \multirow{3}{*}{$\begin{array}{l}\text { PRODUKTY TURY- } \\
\text { STYCZNE ZLOŻONE }\end{array}$} & IMPREZA & $\begin{array}{l}\text { Wczasy } \\
\text { Wycieczka } \\
\text { Obóz wędrowny }\end{array}$ \\
\hline & SZLAK & $\begin{array}{l}\text { Szlak pieszy } \\
\text { Szlak rowerowy } \\
\text { Szlak konny } \\
\text { Szlak samochodowy } \\
\end{array}$ \\
\hline & MIEJSCE & $\begin{array}{l}\text { Miejscowość } \\
\text { Powiat } \\
\text { Region }\end{array}$ \\
\hline
\end{tabular}

Źródło: opracowanie własne na podstawie J. Kaczmarek, A. Stasiak, B. Włodarczyk, Produkt turystyczny, „Turystyka i hotelarstwo” 2002/1, s. 38.

Warto wspomnieć o klasyfikacji produktów turystycznych przedstawionej przez Zygmunta Kruczka ${ }^{22}$ przy uwzględnieniu kryterium sfer odniesienia. Wyróżnia on produkt przedsiębiorstwa i miejsca docelowego. Pierwszy z nich jest zestawem lub pakietem różnorodnych usług, które mają zaspokajać potrzeby turystów i są oferowane przez organizatora turystyki. W drugim przypadku chodzi o region lub miejscowość, które mają do zaoferowania atrakcje turystyczne, infrastrukturę i usługi, jak również o dostępność, wizerunek i cenę, jaką płaci turysta.

${ }^{22}$ Z. Kruczek, B. Walas, Nowoczesne postrzeganie promocji kulturowych produktów turystycznych, [w:] Kultura i turystyka - wspólnie zyskać, red. A. Stasiak, Wydawnictwo Wyższej Szkoły Turystyki i Hotelarstwa, Łódź 2009, s. 337. 


\section{SPECYFIKA PRODUKTU TURYSTYCZNEGO}

Istotną część produktu turystycznego stanowią usługi, co ma niebagatelny wpływ na jego specyfikę. Produkt turystyczny jest odrębny względem innych produktów. Przejawia się to $\mathrm{w}$ tym, że $\mathrm{e}^{23}$ :

- jest konsumowany w miejscu wytworzenia, przy czym produkcja i konsumpcja często zachodzą w tym samym miejscu i czasie;

- $\quad$ nie ma możliwości magazynowania i przechowywania go, gdyż wielkość konsumpcji zależy bezpośrednio od wielkości popytu;

- jest nieprzenośny, co oznacza, że nie można go transportować, natomiast muszą zostać do niego dowiezieni turyści;

- $\quad$ konsument w chwili zakupu nie ma możliwości poznania produktu, dlatego w rzeczywistości nabywa wyobrażenie o wczasach, obietnice udanego wypoczynku oraz stereotypy o docelowym miejscu podróży;

- $\quad$ wytwórca jest przygotowany do ponoszenia wysokich kosztów stałych, co wiąże się z nastawieniem na świadczenie usług w każdej chwili.

Ponadto można stwierdzić, że specyfika produktu turystycznego tkwi w jego:

- $\quad$ złożoności (tworzy go mniejsza lub większa liczba usług oraz dóbr materialnych, które mogą być wobec siebie zarówno substytucyjne, jak i komplementarne);

- różnorodności (usługi tworzące produkt turystyczny bywają niestandardowe, niejednolite i bardzo urozmaicone);

- $\quad$ elastyczności (produkt turystyczny może występować, oprócz wersji podstawowej, w różnych formach dostosowanych do potrzeb turysty);

- $\quad$ sezonowości (poszczególne produktu turystyczne mają okresy wzmożonego popytu na nie, zarówno w przekroju rocznym, tygodniowym czy dziennym);

- $\quad$ konieczności aktywnego zaangażowania turysty (przy pasywności lub niezdyscyplinowaniu turysta nie skorzysta w pełni z produktu lub będzie niezadowolony);

- $\quad$ nieuchwytności (produkt można ocenić po jego konsumpcji);

- abstrakcyjności (turysta dokonuje zakupu „udanego urlopu”, ,możliwości uczestnictwa w ciekawej imprezie", czyli abstrakcyjnej wartości trudnej do opisania przed jej poznaniem, a nie zestawu usług);

- $\quad$ postrzeganiu przez turystów, którzy często mają nadmierne oczekiwania, co może prowadzić do rozbieżności między wyobrażeniami turystów a rzeczywistością;

- $\quad$ szybkiej malejącej użyteczności krańcowej, co przejawia się ciągłym poszukiwaniem przez turystów nowych wrażeń i odwiedzania nowych miejsc;

- $\quad$ publicznym charakterze wielu elementów produktu (np. parki narodowe, muzea).

Produkt turystyczny, jak podają Władysław Gaworecki ${ }^{24}$, Irena Jędrzejczyk ${ }^{25}$ i Andrzej Rapacz ${ }^{26}$, aby mógł się utrzymać na konkurencyjnym rynku powinien się charakteryzować następującymi cechami:

\footnotetext{
${ }^{23}$ J. Altkorn, op. cit., s. 20-22.
} 
- $\quad$ użytecznością, czyli powinien zaspokajać potrzeby turystów;

- $\quad$ oryginalnością, czyli powinien wyróżniać się spośród innych ofert;

- $\quad$ spójnością, czyli wszystkie elementy produktu powinny zostać podporządkowane jednej idei.

\section{MARKETINGOWE UJĘCIE PRODUKTU TURYSTYCZNEGO}

Produkt turystyczny inaczej jest postrzegany przez producenta, a inaczej przez konsumenta, jeśli weźmie się pod uwagę kryterium miejsca zajmowanego na rynku usług turystycznych. Ponadto postrzeganie to zależy również od cech, które charakteryzują wspomniane podmioty. Dotyczy to między innymi motywów zakupu, potrzeb klienta, reprezentowanego na rynku segmentu czy kategorii producenta. Mnogość determinantów decydujących o finalnym obrazie produktu turystycznego skłania do formułowania pewnych uogólnień co do poziomów jego postrzegania. Poziomy te są określane jako wymiary produktu. Wymiary te są opisywane przez wartości mierzalne (liczba składników, cena, zakres usług) i niemierzalne - inaczej intuicyjne (emocje, wyobrażenia). Można je podzielić na uniwersalne oraz na wymiary produktu turystycznego z punktu widzenia producenta i klienta. Na uniwersalne wymiary produktu turystycznego składają się:27

- $\quad$ istota produktu;

- $\quad$ produkt rzeczywisty;

- $\quad$ produkt poszerzony.

Istota produktu określana jest również rdzeniem produktu, jądrem produktu, produktem podstawowym lub produktem głównym. Ma niematerialny charakter i w jej skład wchodzą wszystkie podstawowe potrzeby przejawiane przez turystów, a więc wypoczyn$\mathrm{ku}$, zadowolenia czy poznania. Ten wymiar produktu jest postrzegany przez pryzmat korzyści, jakie wiążą się z jego zakupem. Potrzeby i korzyści są zależne od motywów, dla których podejmowana jest podróż. O ich zgodności decyduje przede wszystkim zrozumienie potrzeb i oczekiwań konsumentów przez producenta.

Produkt rzeczywisty stanowi skonkretyzowaną ofertę sprzedaży, która wskazuje, co konsument otrzymuje za swoje pieniądze. Umożliwia on realizację istoty produktu, czyli zaspokojenie potrzeb turysty. Do tej kategorii zaliczyć można noclegi, posiłki, wycieczki. Składniki produktu rzeczywistego są zmienne i zależą od wzrostu zamożności społeczeństwa, jego rozwoju cywilizacyjnego oraz kulturowego i pod tym kątem są modyfikowane. Dzięki temu produkt ulega ciągłemu poszerzaniu, jego nowe elementy stają się standardem, a także przeważnie wzrasta jego jakość.

Produkt poszerzony nazywany jest także ulepszonym, powiększonym lub wzbogaconym $^{28}$. W jego skład wchodzą dodatkowe świadczenia, które sprawiają, że sam produkt podnosi swoją atrakcyjność. Produkt poszerzony może służyć: zaspokojeniu potrzeb turystów na wyższym poziomie jakościowym, zaproponowaniu dodatkowych korzyści lub

${ }^{24}$ W.W. Gaworecki, Turystyka, PWE, Warszawa 1997, s. 231-233; G. Gołembski, Przedsiębiorstwo turystyczne w gospodarce wolnorynkowej, Akademia Ekonomiczna w Poznaniu, Poznań 1998, s. 27-28 i 41.

${ }^{25}$ I. Jędrzejczyk, Nowoczesny biznes turystyczny. Ekostrategie w zarzadzaniu firma, Wydawnictwo Naukowe PWN, Warszawa 2000, s. 156-157.

${ }^{26}$ Przedsiębiorstwo turystyczne na rynku, red. A. Rapacz, Wydawnictwo Akademii Ekonomicznej im. Oskara Langego we Wrocławiu, Wrocław 1998, s. 242-243.

${ }^{27}$ Kompedium wiedzy o turystyce, s. 69-70.

${ }^{28}$ J. Kaczmarek, A. Stasiak, B. Włodarczyk, op. cit., s. 45. 
próbie wyróżnienia produktu spośród innych. Oferta związana z produktem poszerzonym jest narzędziem do walki na konkurencyjnym rynku. Podobnie jak produkt rzeczywisty, produkt poszerzony charakteryzuje się zmiennością i z upływem czasu poszczególne jego elementy mogą stawać się standardowymi ${ }^{29}$.

Szczególnym wymiarem produktu z punktu widzenia producenta (np. touroperatora) jest produkt potencjalny. Zawiera on w sobie elementy, które w przyszłości mogą wchodzić w skład produktu turystycznego. W danym momencie na skutek przyczyn ekonomicznych, technologicznych, politycznych lub innych nie mogą one być włączone do oferty. Przykładem może być park rozrywki, który zostanie otwarty za dwa lata, a obecnie jest $w$ budowie.

Z punktu widzenia turysty szczególny wymiar produktu turystycznego jest tworzony przez:

- $\quad$ produkt oczekiwany;

- produkt psychologiczny.

Produkt oczekiwany dotyczy cech oraz warunków, jakich oczekują turyści, podejmując decyzję o nabyciu produktu. Produkt oczekiwany istnieje po części w sferze wyobrażeń konsumenta i, jak podaje Victor Middleton ${ }^{30}$, obejmuje:

- $\quad$ wszelkie oczekiwania klienta, czyli wyobrażenia o podróży i pobycie;

- $\quad$ usługi, które klient nabywa (przejazd koleją, ubezpieczenie, transfer z lotniska do hotelu, opiekę przewodnika);

- coś abstrakcyjnego, czyli elementy, takie jak czas (kiedy turysta wyjeżdża), przestrzeń (miejsce, do którego zmierza) i osobę (z kim podróżuje), które są różne u poszczególnych turystów;

- coś krótkotrwałego, co wiąże się z przemijaniem produktu i możliwością ponownego jego przeżywania podczas pokazywania zdjęć i opowiadań o wyjeździe.

Wymienione elementy są często determinowane posiadanym doświadczeniem turystycznym. W procesie sprzedaży produktu turystycznego mogą wystąpić trzy sytuacje:

- produkt oczekiwany jest bardziej rozbudowany niż produkt rzeczywisty i poszerzony (niekorzystna opcja dla producenta),

- produkt oczekiwany oraz rzeczywisty i poszerzony są tożsame,

- produkt rzeczywisty i poszerzony przerasta produkt oczekiwany (korzystna opcja dla producenta).

Ostatnia z opisywanych sytuacji pozwala na uzyskanie efektu zaskoczenia turysty i wyznacza wysoką jakość oferowanego produktu.

Produkt psychologiczny tworzą wszystkie przeżycia turysty, jakie pozostają w jego świadomości od momentu zetknięcia się z produktem aż po zakończeniu konsumpcji. W chwili gdy konsument poszukuje informacji o produkcie, rodzą się w nim określone emocje. Najbardziej są one jednak odczuwalne podczas procesu konsumpcji produktu. Mogą one mieć zarówno zabarwienie pozytywne, jak i negatywne. Pozytywne emocje mogą dotyczyć wrażenia wyjątkowości z dokonanego zakupu, doświadczania komfortu czy relaksu. Negatywne emocje wiążą się z poczuciem zmęczenia, nietrafności dokonane-

\footnotetext{
${ }^{29}$ Ibidem, s. 46.

${ }^{30}$ V.T.C. Middleton, Marketing $w$ turystyce, PAPT, Warszawa 1996, s. 88.
} 
go zakupu, strachu. R. Seweryn ${ }^{31}$ emocje określa jako satysfakcje i dzieli je szczegółowo na:

- $\quad$ satysfakcję w sensie fizjologicznym, która wiąże się z zaspokojeniem podstawowych potrzeb, takich jak sen, wypoczynek, skorzystanie z urządzeń sanitarnych, zaspokojenie głodu, poczucie bezpieczeństwa;

- $\quad$ satysfakcję w sensie psychicznym, która zależy od prawidłowego zaspokojenia potrzeb estetycznych (np. porządek w pokoju), uczuciowych (nawiązanie nowych przyjaźni), związanych z prestiżem (np. udział w wyjeździe o charakterze elitarnym);

- $\quad$ satysfakcję w sensie społecznym, która rodzi się w wyniku zaspokojenia potrzeb społecznych, takich jak potrzeba kontaktu z miejscową ludnością, potrzeba przynależności (do grupy, z którą się podróżuje), potrzeba akceptacji i zrozumienia (przez członków grupy);

- $\quad$ satysfakcję w sensie ekonomicznym, która powstaje wtedy, gdy cena produktu odpowiada jego jakości.

Rozczarowanie pojawia się wtedy, gdy poziom zaspokojenia potrzeb zostaje obniżony w stosunku do stanu wyjściowego. W porównaniu z pozostałymi wymiarami postrzegania produktu produkt psychologiczny jest najbardziej rozłożony w czasie.

Tabela 2. Wymiary postrzegania produktu turystycznego

\begin{tabular}{|c|c|c|}
\hline & Konsumenci - turyści & Producenci \\
\hline \multirow{3}{*}{$\begin{array}{c}\text { Uniwersalne wymiary } \\
\text { produktu turystycznego }\end{array}$} & \multicolumn{2}{|c|}{ ISTOTA PRODUKTU } \\
\cline { 2 - 3 } & \multicolumn{2}{|c|}{ PRODUKT RZECZYWISTY } \\
\cline { 2 - 3 } & \multicolumn{2}{|c|}{ PRODUKT POSZERZONY } \\
\hline \multirow{3}{*}{$\begin{array}{c}\text { Szczegółowe wymiary } \\
\text { produktu turystycznego }\end{array}$} & PRODUKT OCZEKIWANY & PRODUKT POTEN- \\
\cline { 2 - 3 } & CJALNY \\
& GICZNY & \\
\hline
\end{tabular}

Źródło: opracowanie własne na podstawie: J. Kaczmarek, A. Stasiak, B. Włodarczyk, Produkt turystyczny, „Turystyka i hotelarstwo” 2002/1, s. 48.

Dla turystów i twórców produktu turystycznego ten sam produkt może mieć różną wartość. Przedstawione wymiary produktu turystycznego można ujać w dwie kategorie. Pierwszą z nich są poziomy rzeczywiste, czyli produkt rzeczywisty, poszerzony i oczekiwany. Można im przyporządkować wymiary, które mogą dotyczyć liczby usług wchodzących w skład produktu, ceny, zakresu i standardu usług. Drugą kategorią są poziomy psychologiczne (istota produktu, produkt oczekiwany i psychologiczny) i mierzy się je charakterem odczuć, poziomem emocji czy trafnością wyobrażeń. Nieustanne doskonale-

\footnotetext{
${ }^{31}$ R. Seweryn, Produkt turystyczny i wyznaczniki jego atrakcyjności, „Zeszyty Naukowe Akademii Ekonomicznej w Krakowie" 2005/697, s. 73-74.
} 
nie oraz rozwój produktu zmierzają do stworzenia produktu idealnego, a jest nim produkt potencjalny. Stanowi on wersję przyszłościową i ujmuje zagadnienie ciągłego dostosowywania produktów do zaspokojenia potrzeb nabywców na satysfakcjonującym poziomie (tab. 2).

Poszczególne wymiary produktu przejawiają się na różnych etapach „przeżywania produktu turystycznego", do których zalicza się:32

- fazę przygotowań (poszukiwanie i zakup odpowiedniej oferty, przygotowanie do wyjazdu);

- fazę konsumpcji (od momentu opuszczenia przez turystę domu do momentu jego powrotu);

- fazę wspomnień (występuje po zakończeniu konsumpcji).

Każdą z faz charakteryzuje różny poziom nasilenia odczuć, emocji czy wyobrażeń zarówno w sensie pozytywnym, jak i negatywnym. W fazie poszukiwań ofert jest on niewielki, potem rośnie wraz z przygotowaniami do wyjazdu i osiąga kulminację w trakcie konsumpcji. Najdłużej trwa faza wspomnień, które wraz z upływem czasu ulegają powolnemu wygaszeniu. Analizując poszczególne fazy, można stwierdzić, że turysta wybiera się w tę samą podróż aż trzykrotnie. Za pierwszym razem jest to podróż ,palcem po mapie", za drugim przemierza szlak, na przykład pielgrzymkę do Santiago de Compostela, a za trzecim wspomina podróż, przeglądając zdjęcia czy dzieląc się wrażeniami ze znajomymi.

Analiza „przeżywania” produktu turystycznego stała się podstawą do sformułowania jego definicji przez Jacka Kaczmarka ${ }^{33}$. Za produkt turystyczny uznaje on zintegrowany układ oczekiwań, korzyści i wrażeń, które tworzą kompozycję trzech rodzajów podróży: wyobrażonej, rzeczywistej i zapamiętanej. Podróż wyobrażona stanowi inspirację do podjęcia decyzji o rezerwacji miejsca wypoczynku. Dokonuje się ona na podstawie informacji o regionie (mogą być one zawarte w katalogach biur podróży, na stronach internetowych lub w innych środkach masowego przekazu), do którego zamierza się udać turysta. Podróż rzeczywista rozpoczyna się w momencie wyjazdu do miejsca wypoczynku i obejmuje wrażenia i przeżycia związane $\mathrm{z}$ atrakcjami turystycznymi poznawanymi podczas urlopu oraz z atmosferą miejsca zakwaterowania, a także satysfakcję z konsumowanych posiłków w punktach wyżywienia. Na podróż zapamiętaną składają się wspomnienia oraz kontakty po wizycie.

\section{WPLYW OTOCZENIA ZEWNĘTRZNEGO A PODEJŚCIE DO ZAGADNIE- NIA PRODUKTU TURYSTYCZNEGO}

Zachodzące nieustannie zmiany w gospodarce światowej kształtują warunki funkcjonowania poszczególnych branż i podmiotów gospodarczych. Pojawiające się trendy sprawiają, że ewoluuje podejście do poszczególnych zjawisk, procesów czy pojawiających się problemów. Stefan Bosiacki ${ }^{34}$ wskazuje na diametralne zmiany, jakie nastąpiły w ostatnich latach w kwestii tworzenia produktów turystycznych. Zaznacza, że jeszcze nie tak dawno produkt turystyczny był budowany na bazie istniejącego zagospodarowania tury-

\footnotetext{
32 J. Kaczmarek, A. Stasiak, B. Włodarczyk, op. cit., s. 49.

${ }^{33}$ Ibidem, s. 50.

${ }^{34}$ S. Bosiacki, Regionalne produkty turystyczne jako podstawa zagospodarowania turystycznego, „Zeszyty Naukowe Uniwersytetu Szczecińskiego” 2007/465, „Ekonomiczne Problemy Turystyki” 8, s. 20.
} 
stycznego. Obecnie najpierw przystępuje się do konstrukcji zintegrowanego produktu turystycznego obszaru i włącza się do udziału wszystkich zainteresowanych. Równocześnie lub później przeprowadza się przedsięwzięcia pod kątem uzupełnienia bazy turystycznej o nowe elementy lub zmodernizowania istniejącej. Tak konstruowaną ofertę dla turystów określa się jako zintegrowany produkt turystyczny, który można również nazwać sieciowym produktem turystycznym. Warunkiem powstania jest uczestnictwo wielu partnerów przy jego tworzeniu. Jest to podyktowane możliwością osiągnięcia dodatkowych efektów skali w zakresie promocji, rozwoju infrastruktury, zasobów ludzkich i systemu dystrybucji. Jednym z zadań realizowanego w Polsce projektu doradczo-badawczego „Turystyka wspólna sprawa” w latach 2006-2008 była właśnie poprawa umiejętności tworzenia, rozwijania i promowania markowych produktów turystycznych w formule sieciowej. W ramach projektu stworzono 59 grup partnerskich, które opracowały aż 94 pomysły na sieciowe produkty turystyczne ${ }^{35}$.

W Polsce są realizowane także projekty, które mają na celu propagowanie i upowszechnianie produktów turystycznych. Polska Organizacja Turystyczna dzięki dofinansowaniu ze środków unijnych od stycznia 2010 roku do października 2012 roku pilotowała projekt „Promowanie zrównoważonego rozwoju turystyki”. Jego celem było zwiększenie zainteresowania ofertą turystyczną województw Polski Wschodniej (województw warmińsko-mazurskiego, podlaskiego, lubelskiego, podkarpackiego oraz świętokrzyskiego). Kampania przedstawiała Polskę Wschodnią jako miejsce aktywnego wypoczynku, co miało się przełożyć na wzrost liczby odwiedzających, na czym skorzystali przedsiębiorcy z branży turystycznej, samorządy, organizacje pozarządowe i mieszkańcy ${ }^{36}$. Wzmocnieniu wizerunku oferty turystycznej Polski służy także projekt „Promujmy Polskę Razem”. Jego realizacja obejmuje lata 2009-2015. Projekt zakłada działania promocyjne prowadzone z wykorzystaniem nowoczesnych narzędzi marketingowych, stworzenie zintegrowanego i efektywnego systemu informacji turystycznej oraz organizację szkoleń, konferencji, warsztatów i podróży studyjnych w celu pozyskiwania, upowszechniania i wymiany wie$\mathrm{dzy}^{37}$.

\section{ZAKOŃCZENIE}

W poszczególnych definicjach produktu turystycznego akcentuje się konkretne aspekty w zależności od czynników decydujących o sukcesie rynkowym danej strony uczestniczącej w procesie wymiany. Na przykład Kotler widzi w produkcie „wiązkę korzyści”, prezentując podejście konsumenckie do zagadnienia, natomiast Kripendorf wymienia części składowe produktu, czyli podchodzi do problemu od strony podażowej. W definiowaniu produktu turystycznego dominuje podejście strukturalne - na przykład definicje Rogozińskiego, Kaczmarka.

Jednoznaczne przyporządkowanie danego elementu budującego potencjał turystyczny regionu do kategorii ,,produkt” nie jest możliwe ze względu na złożony charakter samego produktu. Przykładowo Stasiak ${ }^{38}$ szlaki turystyczne traktuje nie tylko jako samodzielnie

\footnotetext{
${ }^{35}$ http://www.parp.gov.pl/index/more/24 (dostęp: 15.04.2015).

${ }^{36} \mathrm{http} / / / w w w . p o t . g o v . p 1 / 6-4$ fundusze-ue/p/promocja-polski-wschodniej-v-1 (dostęp: 5.12.2015).

${ }^{37} \mathrm{http}: / /$ www.pot.gov.pl/6-4fundusze-ue/i/promujmy-polske-razem (dostęp: 5.12.2015).

${ }^{38}$ A. Stasiak, Szlaki turystyczne - zagospodarowanie, atrakcje czy produkt turystyczny?, Polskie Towarzystwo Turystyczno-Krajoznawcze Zarząd Główny, 2007, w http://hdl.handle.net/11089/3544, s. 12-13 (dostęp: 13.04.2015).
} 
funkcjonujące produkty turystyczne, ale również jako ważną składową część produktu turystycznego touroperatora (produktu turystycznego - impreza) lub obszaru recepcji turystycznej (produktu turystycznego - obszar), element zagospodarowania turystycznego (oznakowana ścieżka, która umożliwia turystom dotarcie do celu) oraz jako atrakcję turystyczną (np. trasa widokowa). Ponadto może dochodzić do nakładania się na siebie różnych rodzajów produktu lub występowania elementów tworzących produkt w wielu jego rodzajach. Szlak Architektury Drewnianej w województwie podkarpackim jest tylko częścią tego transgranicznego produktu, który występuje również na Słowacji i Ukrainie. Jednocześnie cerkwie wchodzące w skład produktu Szlak Architektury Drewnianej zlokalizowane w Bieszczadach mogą być również elementem produktu Bieszczady.

Przy prowadzeniu badań nie jest wskazane bazowanie na jednej, uogólnionej i uniwersalnej definicji produktu turystycznego. W zależności od celu, jaki przyświeca konkretnemu procesowi badawczemu, należy uściślać to pojęcie, posiłkując się kryterium geograficznym, dyscypliny naukowej, w której ramach prowadzone są badania, postrzegania produktu turystycznego czy stopnia jego złożoności.

\section{LITERATURA}

[1] Altkorn J., Marketing w turystyce, Wydawnictwo Naukowe PWN, Warszawa 1997.

[2] Bosiacki S., Regionalne produkty turystyczne jako podstawa zagospodarowania turystycznego, „Zeszyty Naukowe Uniwersytetu Szczecińskiego” 2007/465, „Ekonomiczne Problemy Turystyki" 8.

[3] Dietl J., Marketing, PWE, Warszawa 1981.

[4] Fijałkowski D., Produkt turystyczny w ujęciu marketingowym, „Słupskie Prace Geograficzne” 2003/1.

[5] Gaworecki W.W., Ekonomika i organizacja turystyki, Państwowe Wydawnictwo Naukowe, Warszawa 1978

[6] Gaworecki W.W., Turystyka, PWE, Warszawa 1997, s. 231-233.

[7] Gołembski G., Przedsiębiorstwo turystyczne w gospodarce wolnorynkowej, Akademia Ekonomiczna w Poznaniu, Poznań 1998.

[8] Jędrzejczyk I., Nowoczesny biznes turystyczny. Ekostrategie w zarzqdzaniu firma, Wydawnictwo Naukowe PWN, Warszawa 2000.

[9] Kaczmarek J., Stasiak A., Włodarczyk B., Produkt turystyczny, ,Turystyka i hotelarstwo” 2002/1.

[10] Kaspar C., Kunz B., Unternehmungsführung im Fremdenverkehr, Stuttgart, Bern, 1982.

[11] Kompedium wiedzy o turystyce, red. G. Gołembski, PWN, Warszawa-Poznań 2005.

[12] Kotler Ph., Principles of Marketing. Englewood Cliffs, Prentice Hall, Englewood Cliffs 1980.

[13] Krippendorf J., Marketing im Fremdenverker, Bern-Frankfurt 1971.

[14] Kruczek Z., Walas B., Nowoczesne postrzeganie promocji kulturowych produktów turystycznych, [w:] Kultura i turystyka - wspólnie zyskać, red. A. Stasiak, Wydawnictwo Wyższej Szkoły Turystyki i Hotelarstwa, Łódź 2009.

[15] Nowacki M., Szlaki dziedzictwa naturalnego i kulturowego droga ku turystyce kreatywnej, [w:] Kultura i turystyka. Wspólna droga, red. B. Włodarczyk, Krakowiak B., Latosińska J., Regionalna Organizacja Turystyczna Województwa Łódzkiego, Łódź 2011.

[16] Medlik S., Leksykon podróży, turystyki i hotelarstwa, Państwowe Wydawnictwo Naukowe, Warszawa 1995.

[17] Middleton V.T.C., Marketing $w$ turystyce, PAPT, Warszawa 1996.

[18] Panasiuk A., Ekonomika turystyki, Wydawnictwo Naukowe PWN, Warszawa 2007.

[19] Przedsiębiorstwo turystyczne na rynku, red. A. Rapacz, Wydawnictwo Akademii Ekonomicznej im. Oskara Langego we Wrocławiu, Wrocław 1998.

[20] Rogalewski O., Zagospodarowanie turystyczne, Wydawnictwa Szkolne i Pedagogiczne, Warszawa 1979. 
[21] Rogoziński K., Marketing na rynku turystycznym, „Handel Wewnętrzny” 1977/4.

[22] Seweryn R., Produkt turystyczny $i$ wyznaczniki jego atrakcyjności, „Zeszyty Naukowe Akademii Ekonomicznej w Krakowie" 2005/697.

[23] Stasiak A., Produkt turystyczny w gospodarce doświadczeń, „Turyzm” 23/1 (2013).

[24] Zawistowska H., Rola Unii Europejskiej w poprawie jakości produktów turystycznych, [w:] Kierunki rozwoju badań naukowych w turystyce, PWN, Akademia Ekonomiczna w Poznaniu, Warszawa 2003.

\section{MULTIFACETED APPROACH TO THE DEFINITION OF TOURISM}

The author conducted a review of existing tourism product definitions. He responded to the issues of arrangement of heterogeneity of existing tourism product definitions. As the results of own research the paper shows that there are many different ways to define tourism product. Definitions depend on many issues (e.g. the purpose of the study, the subject, the range of meaning or the number of elements making up the product). From different stakeholders (studying tourism markets rules) point of view of view it is important to understand the complexity of the phenomenon. The integral part of the tourism product are goods and services. Depending on the author (who defines the tourism product) in the structure of definition it can be distinguished e.g. tourist attractions, tourist infrastructure and accompanying services or basic goods and/or complementary tourist services. Not all components of the tourism product are tangible and therefore, marketing approach to the issue of product „starts" when choosing a place of rest and lasts long after returning with holiday memories. Changes taking place in the global economy initiate the innovative approach when creating tourism products. The best example of changes is integral tourism product built with the help of the local government, the private sector and the local community. The conclusion is that relying on one generalized and universal definition is not desirable in conducting specific research.

Keywords: tourist market, tourist product

DOI: 10.7862/rz.2015.mmr.47

Tekst złożono w redakcji: maj 2015

Przyjęto do druku: wrzesień 2015 